\title{
MACROH2A2 wt Allele
}

National Cancer Institute

\section{Source}

National Cancer Institute. MACROH2A2 wt Allele. NCI Thesaurus. Code C154658.

Human MACROH2A2 wild-type allele is located in the vicinity of $10 \mathrm{q} 22.1$ and is approximately $60 \mathrm{~kb}$ in length. This allele, which encodes core histone macro-H2A.2 protein, is involved in transcriptional repression. 